\title{
Polymorphism rs7023923 and monocyte count in blood donors and coronary artery disease patients
}

\author{
Jarosław Szymon Świrta, Marzena Krzemień-Grandys, Justyna Totoń-Żurańska, Katarzyna Kuś, \\ Rafał Olszanecki, Jacek Jawień, Marcin Wnuk, Agnieszka Słowik, Jacek Godlewski, \\ Krzysztof Żmudka, Ryszard Korbut, Paweł Piotr Wołkow
}

Jagiellonian University Medical College, Krakow, Poland

\begin{abstract}
Background: The importance of the role of monocytes in coronary artery disease (CAD) is well documented. An increased number of circulating monocytes is associated with higher incidence of CAD. Both environmental and genetic factors influence monocytosis. The latter have been extensively studied since the development of high-throughput genome-wide association studies. Several associations between polymorphisms and monocytosis were found among healthy individuals; the first example was rs7023923. The magnitude of the association of studied polymorphisms with the trait of interest is often confounded by environmental factors and may therefore differ between patient and healthy populations. It is very important to determine the magnitude of the association among patients to predict outcome of the disease, e.g. myocardial infarction.

Aim: To determine whether the magnitude of association of rs7023923 with monocytosis, previously reported among healthy volunteers, is similar in patients in whom diagnosis of CAD was determined during elective coronarography.

Methods and results: Leucocytosis and neutrophilocytosis were higher among patients with CAD, while thrombocytosis was lower. Monocyte count did not differ among the studied groups $(p=0.25)$. We confirmed the association of rs7023923 with monocytosis among healthy blood donors $(p=0.0156)$ but not among patients admitted for elective coronarography $(p=0.61)$. Inclusion of the age and sex of patients in the statistical model did not modify the results.

Conclusions: Our data suggest that translation of the results of genetic association with the studied traits from healthy to patient population should be implemented with caution. It is possible that numerous environmental factors, which discriminate healthy volunteers from CAD patients, confound the magnitude of genetic associations and make interpretation of the data in patients less clear.
\end{abstract}

Key words: monocyte count, polymorphism, coronary artery disease, blood donor

Kardiol Pol 2015; 73, 6: 445-450

\section{INTRODUCTION}

Monocytes are a class of agranulocytes, which belong to the mononuclear phagocyte system and constitute $8-12 \%$ of all leukocytes. They develop from the joint myeloid progenitor cell in bone marrow. Mononuclear phagocytes play essential roles in the development of inflammation and host defence. Upon maturation, monocytes circulate freely in blood vessels for several days, but eventually infiltrate peripheral tissues, where they differentiate irreversibly to either macrophages or dendritic cells [1]. Monocytes participate in acute inflammation (e.g. in phagocytosis of pathogens and killing of infected host cells), but also in chronic diseases, in which cytokines are produced in response to antigen presentation [2]. Monocyte count is associated with chronic diseases, e.g. atherosclerosis [3], stroke [4], and peripheral arterial disease [5]. The factors that regulate the monocyte count remain partly unknown.

Clinical studies have demonstrated that monocytes play a key role in atherosclerosis [6, 7], myocardial infarction (MI) [8], 
and healing after $\mathrm{MI}$ [9]. Monocytes are attracted to the coronary artery wall, where they differentiate to macrophages, become loaded with lipids, and remain trapped there. At this point they present as foam cells and their presence contributes to the growth of atherosclerotic plaque, while cytokines produced by monocytes/macrophages may contribute to plaque instability and rupture, with clinical consequences of unstable angina or MI [10].

Basal monocyte count is related to various environmental factors, e.g. age, sex, and ethnicity [11-13]. Changes in circulating monocyte count can occur rapidly, e.g. hours after infection, drug administration, tissue injury, and surgical stress [14]. However, monocyte count changes may also last for a long time, e.g. due to exercise therapy [15] or inflammatory bowel disease [16]. In contrast to environmental factors, relatively little is known about genetic factors that control monocyte count. In 2009, researchers from Queensland Institute of Medical Research in Australia demonstrated the influence of the single nucleotide polymorphism (SNP) rs7023923 on monocyte count in healthy volunteers [17]. This SNP is situated in an intergenic region of chromosome $9 q 31$, near lysophosphatidic acid receptor 1 gene locus and is responsible for $1.5 \%$ of the variation in monocyte counts. The integral membrane protein encoded by this gene is a lysophosphatidic acid receptor (LPAR1), a member of the G protein-coupled receptor superfamily, which mediates diverse biological functions, including proliferation, platelet aggregation, smooth muscle contraction, and chemotaxis [18].

Polymorphisms in the following loci were associated with monocyte count in Japanese subjects: rs12988934 in the ITGA4 locus, rs3095254 in the MHC region, rs10956483 in the MLZE locus, rs10147992 in the STXBP6 locus, and rs9373124 in the HBS1L-MYB locus [19]. In the African American population, several polymorphisms in the Duffy antigen/receptor chemokine gene locus were associated both with total leukocyte and monocyte counts [20]. Both in the European and in mixed ancestry samples, novel associations were identified in the interferon regulatory factor 8 (IRF8) gene, chemokine-binding protein 2 (CCBP2) gene, and in a region of replication found in ribophorin I (RPN1) gene, while previously reported associations near ITGA4 and LPAR1 were confirmed [21]. The CCBP2 and RPN1 region is a site of binding GATA2 transcription factor, previously associated with coronary artery disease (CAD) [22].

Genotyping of polymorphisms, which regulate monocyte count, may help predict risk of deadly complications of CAD, such as MI. However, it is important to know whether the associations between the polymorphisms and monocyte count, readily detectable in healthy subjects, can be replicated in patients under the influence of classical risk factors for atherothrombosis, such as our patients, who were waiting for a coronary artery angiography procedure and were finally diagnosed with CAD. It is possible that environmental factors associated with monocyte count dwarf effects of studied polymorphisms, or even different polymorphisms, become important for monocyte count, due to their interaction with environment.

The goal of our study was to replicate the initial observation of association of polymorphism rs7023923 with monocyte count in a Polish population of healthy blood donors and to verify whether the association of the same magnitude holds true in patients with CAD, confirmed during elective coronary angiography.

\section{METHODS}

Genotyping was performed in two groups: blood donors from south-east Poland (69 genotyped persons) and patients with CAD, confirmed during elective coronary angiography, in the Cardiology Department of John Paul II Hospital in Krakow (26 genotyped patients). Complete blood count, clinical characteristics, age, and sex of patients were obtained from hospital charts. All patients provided written informed consent. The experimental protocol was approved by the Bioethics Committee of the Jagiellonian University. Leukocytes were isolated from anticoagulated venous blood samples by centrifugation. Their DNA was isolated with TRIzol (Life Technologies), according to the manufacturer's protocol. DNA was amplified by polymerase chain reaction (PCR), using primers complementary to the sequence, surrounding the studied polymorphism.

Sequences of primers were the following: forward primer 5'-GAATGTTTTTGACGATTTGGAA and reverse primer 5'-AAGTAGCTGCTAGACTGGCCTTA. The PCR conditions were the following: initial denaturation at $94^{\circ} \mathrm{C}$ for $5 \mathrm{~min}$, followed by 40 cycles of denaturation $\left(94^{\circ} \mathrm{C}\right.$ for $\left.30 \mathrm{~s}\right)$, primer annealing $\left(58^{\circ} \mathrm{C}\right.$ for $\left.45 \mathrm{~s}\right)$ and elongation $\left(72^{\circ} \mathrm{C}\right.$ for $\left.45 \mathrm{~s}\right)$, ending with storage at $4^{\circ} \mathrm{C}$ until further analysis. Platinum Hot Start Polymerase (Life Technologies) was used for amplification.

Digestion of the PCR product with Fatl enzyme (Fermentas), selected based on RestrictionMapper analysis, was performed according to the manufacturer's protocol during $14 \mathrm{~h}$, at a temperature of $55^{\circ} \mathrm{C}$, followed by $20 \mathrm{~min}$ at $65^{\circ} \mathrm{C}$ to inactivate the enzyme. Digestion products were separated by agarose gel electrophoresis with the addition of ethidium bromide. Genotypes were inferred after UV light transillumination of the gel.

Primers were designed to be complementary to the non-repetitive DNA in this locus to avoid nonspecific PCR products. The result of the reaction was a product $173 \mathrm{bp}$ long. Fatl is potentially capable of cutting this product into two fragments, $141 \mathrm{bp}$ and $32 \mathrm{bp}$ long. Since the short fragment is difficult to visualise on the agarose gel and can be easily misinterpreted in the presence of primer band, we based the results on the identification of large fragments. Use of restriction enzyme resulted in our samples in one of three possible patterns visible on the gel: a single $173 \mathrm{bp}$ band in the case 


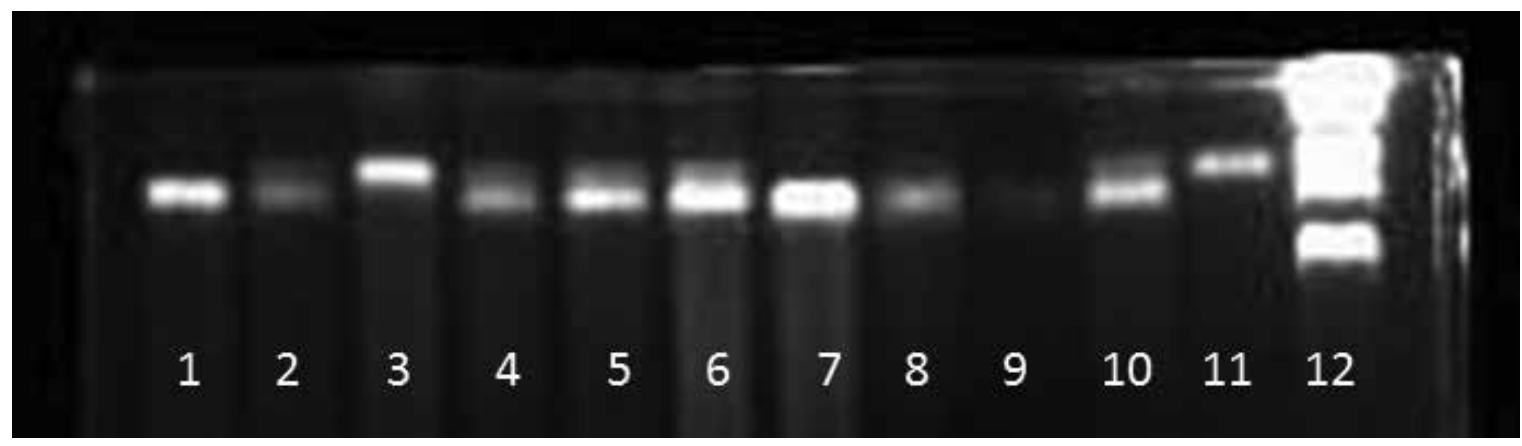

Figure 1. Results of restriction enzyme digestion of the polymerase chain reaction product: a) lanes 1, 7-8 (product 141 bp, double cut homozygotes); b) lanes 2, 4-6, 10 (products $173 \mathrm{bp}$ and $141 \mathrm{bp}$, single cut heterozygotes); c) lanes 3 and 11 (product 173 bp, no cut homozygotes; d) lane 9 - too weak product, required repeated analysis; e) lane 12 — DNA marker

of no-cut homozygotes, two bands of $173 \mathrm{bp}$ and $141 \mathrm{bp}$ in the case of single allele cut heterozygotes, and a single band of $141 \mathrm{bp}$ in the case of double allele cut homozygotes. An example of gel image interpretation is shown in Figure 1.

\section{Statistical analysis}

Wilcoxon test was used to compare counts of morphotic elements between the studied groups. Non-parametric Kruskal-Wallis test was used to evaluate the association of the genotypes with blood count of morphotic elements. Linear regression was used to account for the age and sex of the patients. Analysis was performed with SAS v. 9.3 (Cary, USA). $P$ values less than 0.05 were considered statistically significant. Bonferroni correction for multiple testing was applied.

\section{RESULTS}

Distribution of sexes was similar in both studied groups: $85.3 \%$ of males among blood donors, compared to $78.6 \%$ among patients subjected to coronary angiography $(p=0.53)$. Not surprisingly, blood donors were significantly younger than patients suspected of CAD: $34.0 \pm 10.0$ compared to $57.3 \pm 12.0$ years of age $(p<0.0001)$.

Complete blood count parameters were compared between the two studied groups. The results are presented in Table 1.

The data show that patients admitted for elective angioplasty have significantly higher leukocyte and neutrophil counts, but also significantly lower platelet count, compared to healthy blood donors. The erythrocyte, lymphocyte, and monocyte counts were not different between the studied groups. The clinical characteristics of the patients admitted for coronary angiography are presented in Table 2.

The distribution of genotypes was the following: in the healthy donor group CC ( $\mathrm{n}=33 ; 47.8 \%)$, CT $(\mathrm{n}=16 ; 23.2 \%)$, and TT ( $\mathrm{n}=20 ; 29.0 \%)$; and in the group of patients with angiography CC $(\mathrm{n}=12 ; 46.2 \%), \mathrm{CT}(\mathrm{n}=8 ; 30.8 \%)$, and TT $(\mathrm{n}=6 ; 23.1 \%)$. Therefore, the distribution of alleles in the healthy donor group was as follows: $\mathrm{C}(\mathrm{n}=82 ; 59.4 \%)$ and
Table 1. Comparison of morphotic element counts in blood of healthy blood donors and coronary artery disease suspects, admitted for elective angiography

\begin{tabular}{lccc} 
Variable & \multicolumn{2}{c}{ Studied groups } & P \\
\cline { 2 - 3 } & $\begin{array}{c}\text { Blood donors } \\
(\mathbf{n}=\mathbf{6 9})\end{array}$ & $\begin{array}{c}\text { Elective } \\
\text { angiography } \\
(\mathbf{n}=\mathbf{2 6})\end{array}$ \\
\hline Erythrocytes & $4.95 \pm 0.47$ & $4.88 \pm 0.27$ & 0.52 \\
Leukocytes & $6.45 \pm 1.24$ & $8.54 \pm 2.53$ & 0.0003 \\
Platelets & $269.07 \pm 56.10$ & $212.64 \pm 48.07$ & 0.0011 \\
Neutrophils & $3.55 \pm 1.05$ & $5.73 \pm 2.40$ & $<0.0001$ \\
Lymphocytes & $2.10 \pm 0.54$ & $3.24 \pm 3.96$ & 0.24 \\
Monocytes & $0.50 \pm 0.18$ & $0.55 \pm 0.16$ & 0.25 \\
\hline
\end{tabular}

Mean \pm standard deviation values. Erythrocytes $(\mathrm{m} / \mathrm{n} / \mu \mathrm{L})$, other (thousand $/ \mu \mathrm{L}$ ). Wilcoxon test $\mathrm{p}$ values, uncorrected for multiple testing, are shown. P values for leukocyte, neutrophil, and platelet count remain significant after Bonferroni correction.

Table 2. Clinical characteristics of patients subjected to elective coronary angioplasty $(n=26)$

\begin{tabular}{|lc|}
\hline Variable & Value \\
\hline Final diagnosis of coronary artery disease & $100 \%$ \\
Age [years] & $59.1 \pm 10.9$ \\
Male sex & $78.6 \%$ \\
Cardiovascular comorbidities: & \\
Paroxysmal atrial fibrillation & 2 \\
Congestive heart failure & 2 \\
Cardiomyopathy & 1 \\
Diabetes mellitus, type 2 & $32.1 \%$ \\
Lipid metabolism disorder & $85.7 \%$ \\
Obesity & $21.4 \%$ \\
Current smoking & $3.6 \%$ \\
Arterial hypertension & $85.7 \%$ \\
C-reactive protein [mg/L] & $3.81 \pm 3.0$ \\
\hline
\end{tabular}


Table 3. Association of rs7023923 genotypes with morphotic element counts in blood of healthy donors $(n=69)$

\begin{tabular}{lcccc} 
Variable & \multicolumn{3}{c}{ Genotypes of rs7023923 } & P \\
\cline { 2 - 4 } & $\mathbf{C C}(\mathbf{n}=\mathbf{3 3})$ & $\mathbf{C T}(\mathbf{n}=\mathbf{1 6})$ & TT $(\mathbf{n}=\mathbf{2 0})$ \\
\hline Erythrocytes & $4.97 \pm 0.45$ & $5.01 \pm 0.42$ & $4.86 \pm 0.55$ & 0.42 \\
Leukocytes & $6.68 \pm 1.06$ & $6.39 \pm 1.56$ & $6.17 \pm 1.17$ & 0.25 \\
Platelets & $260.23 \pm 66.10$ & $267.78 \pm 47.80$ & $282.81 \pm 45.91$ & 0.13 \\
Neutrophils & $3.65 \pm 0.90$ & $3.37 \pm 1.39$ & $3.54 \pm 0.93$ & 0.18 \\
Lymphocytes & $2.16 \pm 0.62$ & $2.24 \pm 0.49$ & $1.90 \pm 0.41$ & 0.12 \\
Monocytes & $0.57 \pm 0.21$ & $0.41 \pm 0.14$ & $0.48 \pm 0.12$ & 0.0026 \\
\hline
\end{tabular}

Erythrocytes $(\mathrm{m} / \mathrm{n} / \mu \mathrm{L}$ ), other (thousand/ $\mu \mathrm{L})$. P values for Kruskal-Wallis test, comparing count of each morphotic element across the genotype strata, uncorrected for multiple testing. Bonferroni corrected $p$ value for monocytes $=0.0156$.

Table 4. Association of rs7023923 genotypes with morphotic element counts in blood of patients with coronary artery disease admitted for angioplasty $(n=26)$

\begin{tabular}{lcccc} 
Variable & \multicolumn{3}{c}{ Genotypes of rs7023923 } & P \\
\cline { 2 - 3 } & $\mathbf{C C}(\mathbf{n}=\mathbf{1 2})$ & $\mathbf{C T}(\mathbf{n}=\mathbf{8})$ & TT $(\mathbf{n}=\mathbf{6})$ \\
\hline Erythrocytes & $4.93 \pm 0.20$ & $4.61 \pm 0.21$ & $5.24 \pm 0.11$ & 0.026 \\
Leukocytes & $8.73 \pm 3.31$ & $8.33 \pm 1.10$ & $8.20 \pm 1.41$ & 0.98 \\
Platelets & $209.50 \pm 44.41$ & $203.50 \pm 66.93$ & $243.50 \pm 21.92$ & 0.44 \\
Neutrophils & $5.86 \pm 3.21$ & $5.65 \pm 0.37$ & $5.35 \pm 1.48$ & 0.77 \\
Lymphocytes & $2.15 \pm 0.42$ & $5.96 \pm 7.33$ & $2.15 \pm 0.07$ & 0.44 \\
Monocytes & $0.57 \pm 0.18$ & $0.49 \pm 0.15$ & $0.56 \pm 0.11$ & 0.61 \\
\hline
\end{tabular}

Mean \pm standard deviation values are provided. Erythrocytes $(\mathrm{m} / \mathrm{n} / \mu \mathrm{L})$, other (thousand/ $\mu \mathrm{L})$. P values for Kruskal-Wallis test, comparing count of each morphotic element across the genotype strata, uncorrected for multiple testing. Bonferroni corrected $p$ value for erythrocytes $=0.156$.

$\mathrm{T}(\mathrm{n}=56 ; 40.6 \%)$, and among patients with angiography: $\mathrm{C}(\mathrm{n}=32 ; 61.5 \%)$ and $\mathrm{T}(\mathrm{n}=20 ; 38.5 \%)$.

The association of polymorphism rs7023923 with count of blood morphotic elements in healthy blood doors is summarised in Table 3.

The data show that polymorphism rs7023923 is associated with monocyte count, but not with the count of any other morphotic element in healthy blood donors. The association remains significant after Bonferroni correction for multiple testing.

We also evaluated whether a similar association remains significant among patients with CAD, admitted for elective coronary angiography. The data are presented in Table 4.

The data show that the association observed among healthy people is not significant among patients with CAD confirmed during elective angiography. The monocyte count is not significantly associated with genotypes of rs7023923 polymorphism $(p=0.61)$, and neither is the count of any other morphotic element. While erythrocyte count is significantly associated with this polymorphism ( $p=0.026)$, correction for multiple testing ( $p=0.156$ ) abolished this relationship.

We used logistic regression to correct the results from Tables 1 and 3 for age and sex of blood donors and of patients; however, this did not modify the significance of the associa- tions. Our data suggest that factors other than the studied polymorphism affect the monocyte count in sick people. The influence of genetic factors, determined among healthy people, may be less relevant during disease. Factors such as patients' classical risk factors of CAD may be more powerful players, and their interaction with genetic effects may dwarf in consequence the relevance of the latter.

\section{DISCUSSION}

Our analysis confirmed that the previously reported association of polymorphism rs7023923 is valid also among healthy blood donors in Poland. However, the same association could not be demonstrated among patients with CAD, admitted to the hospital for elective coronary angiography. This is probably due to the fact that environmental factors, coming into play in CAD patients, modify the studied association.

An issue of genetic control over clinical parameters is of great importance for future diagnostic tests, aimed to stratify the population by the risk of developing the specific disease. It is quite likely that people with a higher number of monocytes circulating in blood may be prone to develop atherosclerosis and its deadly complications, such as MI or stroke. The possible underlying mechanism is that the high number of circulating monocytes translates into higher numbers of 
monocytes being attracted to the atherosclerotic plaque. In this case, increased production of proinflammatory cytokines and enhanced presentation of antigens, by the high number of monocytes that turn into macrophages, could increase the chance of plaque destabilisation and rupture.

Genome wide association studies provided, in the past few years, evidence that the majority of complex traits are controlled by multiple genetic polymorphisms. Each SNP has a rather small impact on the studied trait, in sharp contrast to the previously held belief that a handful of polymorphisms would exert a potent effect on the studied trait. The polymorphism rs7023923 and monocyte count trait are no exceptions. Although this association has been replicated in several studies, the overall variance in monocyte count, controlled by this SNP, is only about $1.5 \%$. A recent study demonstrated that this polymorphism upregulates expression of the LPAR1 gene [23]. In our opinion, environmental factors, some of them hard to measure, e.g. patients' fear associated with the elective procedure of coronary angiography and potentially also angioplasty, may exert a much more potent effect on monocyte count than the studied polymorphism. By definition, risk factors of CAD, e.g. smoking and comorbidities such as hypertension or diabetes mellitus, are more prevalent among CAD suspects than in healthy people. It is not known whether there is any interaction between them and polymorphism rs7023923, located near lysophosphatidic acid receptor locus. However, such an interaction cannot be excluded, since lysophosphatidic acid regulates blood glucose concentration [24], accumulates in atherosclerotic lesions, and induces smooth muscle cells to produce cytokines [25].

In this situation, the impact of SNP may be overwhelmed by the large effect of environmental factors, and therefore not detected in a small cohort. We admit that the small number of subjects with CAD is a limitation of our study and should be remedied by further investigations. Another important limitation of our study is the lack of information on the presence of atherothrombosis risk factors among blood donors self-reporting to be healthy. We cannot exclude the possibility that a few of these people had subclinical CAD, leading to patient misclassification.

\section{CONCLUSIONS}

We advise caution when data from the study of quantitative phenotypes are directly translated from a cohort of healthy people to a hospital-based cohort.

\section{Acknowledgements}

This article was supported by grants from the Polish National Centre of Science (NCN): 3258/P01/2007/32, 4689/B/P01/2009/37, N N401 293939, and from statutory funds of the Jagiellonian University Medical College K/ZDS/001488.

Conflict of interest: none declared

\section{References}

1. van der Laan AM, Ter Horst EN, Delewi R et al. Monocyte subset accumulation in the human heart following acute myocardial infarction and the role of the spleen as monocyte reservoir. Eur Heart J, 2014; 35: 376-385.

2. Ingersoll MA, Platt AM, Potteaux S, Randolph GJ. Monocyte trafficking in acute and chronic inflammation. Trends Immunol, 2011; 32: $470-477$.

3. Johnsen SH, Fosse E, Joakimsen O et al. Monocyte count is a predictor of novel plaque formation: a 7-year follow-up study of 2610 persons without carotid plaque at baseline the Tromsø Study. Stroke. 2005; 36: 715-719.

4. Urra X, Villamor N, Amaro S et al. Monocyte subtypes predict clinical course and prognosis in human stroke. J Cereb Blood Flow Metab, 2009; 29: 994-1002.

5. Nasir K, Guallar E, Navas-Acien A et al. Relationship of monocyte count and peripheral arterial disease: results from the National Health and Nutrition Examination Survey 1999-2002. Arterioscler Thromb Vasc Biol, 2005; 25: 1966-1971.

6. Imanishi $\mathrm{T}$, Ikejima $\mathrm{H}$, Tsujioka $\mathrm{H}$ et al. Association of monocyte subset counts with coronary fibrous cap thickness in patients with unstable angina pectoris. Atherosclerosis, 2010; 212: 628-635.

7. Waterhouse DF, Cahill RA, Sheehan F, McCreery C. Prediction of calculated future cardiovascular disease by monocyte count in an asymptomatic population. Vasc Health Risk Manag, 2008; 4: 177-187.

8. Sopel M, Ma I, Gelinas L et al. Integrins and monocyte migration to the ischemic myocardium. J Invest Surg, 2010; 23: 79-86.

9. Majmudar MD, Keliher EJ, Heidt T et al. Monocyte-directed RNAi targeting CCR2 improves infarct healing in atherosclerosis-prone mice. Circulation, 2013; 127: 2038-2046.

10. Tashiro H, Shimokawa H, Yamamoto K et al. Monocyte-related cytokines in acute myocardial infarction. Am Heart J, 1995; 130: 446-452.

11. Evans DM, Frazer IH, Martin NG. Genetic and environmental causes of variation in basal levels of blood cells. Twin Res, 1999; 2: 250-257.

12. Seidler S, Zimmermann HW, Bartneck M et al. Age-dependent alterations of monocyte subsets and monocyte-related chemokine pathways in healthy adults. BMC Immunol, 2010; 11: 30.

13. Saxena S, Wong ET. Heterogeneity of common hematologic parameters among racial, ethnic, and gender subgroups. Arch Pathol Lab Med, 1990; 114: 715-719.

14. Haruki K, Shiba H, Fujiwara Y et al. Perioperative change in peripheral blood monocyte count may predict prognosis in patients with colorectal liver metastasis after hepatic resection. J Surg Oncol, 2012; 106: 31-35.

15. Michishita R, Shono N, Inoue T et al. Effect of exercise therapy on monocyte and neutrophil counts in overweight women. Am J Med Sci, 2010; 339: 152-156.

16. Mee AS, Berney J, Jewell DP. Monocytes in inflammatory bowel disease: absolute monocyte counts. J Clin Pathol, 1980; 33: 917-920.

17. Ferreira MA, Hottenga JJ, Warrington NM et al. Sequence variants in three loci influence monocyte counts and erythrocyte volume. Am J Hum Genet, 2009; 85: 745-749.

18. Lin ME, Herr DR, Chun J. Lysophosphatidic acid (LPA) receptors: signaling properties and disease relevance. Prostaglandins Other Lipid Mediat, 2010; 91: 130-138.

19. Okada Y, Hirota T, Kamatani Y et al. Identification of nine novel loci associated with white blood cell subtypes in a Japanese population. PLoS Genet, 2011; 7: e1002067.

20. Crosslin DR, McDavid A, Weston N et al. Genetic variants associated with the white blood cell count in 13,923 subjects in the eMERGE Network. Hum Genet, 2012; 131: 639-652.

21. Crosslin DR, McDavid A, Weston N et al. Genetic variation associated with circulating monocyte count in the eMERGE Network. Hum Mol Genet, 2013; 22: 2119-2127.

22. Connelly JJ, Wang T, Cox JE. GATA2 is associated with familial early-onset coronary artery disease. PLoS Genet, 2006; 2: e139.

23. Maugeri N, Powell JE, 't Hoen PA et al. LPAR1 and ITGA4 regulate peripheral blood monocyte counts. Hum Mutat, 2011; 32: 873-876.

24. Yea K, Kim J, Lim S et al. Lysophosphatidic acid regulates blood glucose by stimulating myotube and adipocyte glucose uptake. J Mol Med (Berl), 2008; 86: 211-220.

25. Cui MZ. Lysophosphatidic acid effects on atherosclerosis and thrombosis. Clin Lipidol, 2011; 6: 413-426. 


\title{
Polimorfizm rs7023923 i monocytoza u dawców krwi oraz pacjentów z chorobą wieńcową
}

\author{
Jarosław Szymon Świrta, Marzena Krzemień-Grandys, Justyna Totoń-Żurańska, Katarzyna Kuś, \\ Rafał Olszanecki, Jacek Jawień, Marcin Wnuk, Agnieszka Słowik, Jacek Godlewski, \\ Krzysztof Żmudka, Ryszard Korbut, Paweł Piotr Wołkow \\ Uniwersytet Jagielloński, Collegium Medicum, Kraków
}

\section{Streszczenie}

Wstęp: Istotna rola monocytów w chorobie wieńcowej (CAD) jest dobrze udokumentowana. Wzrost ich liczby w krążeniu wiąże się z częstszym występowaniem CAD. Zarówno czynniki środowiskowe, jak i genetyczne wpływają na liczbę monocytów we krwi, te ostatnie zaczęły być poznawane jednak dopiero niedawno, z nadejściem ery badań asocjacyjnych na poziomie całego genomu. Kilka takich asocjacji zidentyfikowano u osób zdrowych, pierwsza znaleziona asocjacja dotyczyła polimorfizmu rs7023923. Wielkość asocjacji między polimorfizmem a badaną cechą jest często modyfikowana przez czynniki środowiskowe i jest różna u chorych w porównaniu ze zdrową populacją. Bardzo ważne jest ustalenie wpływu czynników genetycznych właśnie wśród chorych, aby dokładnie przewidzieć efekt choroby, np. zawał serca.

Cel: Celem badania było stwierdzenie, czy wielkość asocjacji między rs7023923 a liczbą monocytów, uprzednio stwierdzonej u osób zdrowych, jest podobna u pacjentów z CAD potwierdzoną podczas planowego zabiegu koronarografii.

Metody i wyniki: Osoby z CAD charakteryzowały się wyższą leukocytozą i neutrofilocytozą, ale niższą trombocytozą w porównaniu z osobami zdrowymi. Monocytoza nie różniła się między badanymi grupami $(p=0,25)$. Potwierdzono istnienie związku między rs7023923 a monocytozą u zdrowych dawców krwi $(p=0,0156)$, lecz nie u pacjentów przyjętych w celu wykonania koronarografii $(p=0,61)$. Uwzględnienie wieku i płci pacjentów w modelu statystycznym nie modyfikowało rezultatów.

Wnioski: Uzyskane wyniki sugerują, że należy zachować dużą ostrożność podczas translacji wyników asocjacji genetycznej badanych cech od osób zdrowych do populacji chorych. Jest prawdopodobne, że liczne czynniki środowiskowe, którymi różnią się między sobą pacjenci z podejrzeniem CAD od zdrowej populacji, modyfikują stopień asocjacji genetycznej i utrudniają jej interpretację.

Słowa kluczowe: monocytoza, polimorfizm, choroba wieńcowa, dawca krwi

Kardiol Pol 2015; 73, 6: 445-450

\section{Adres do korespondencji:}

dr n. med. Paweł Piotr Wołkow, Katedra Farmakologii, Uniwersytet Jagielloński, Collegium Medicum, ul. Grzegórzecka 16, 31-531 Kraków, e-mail: Pawel.Wolkow@uj.edu.pl 